\title{
DEVELOPMENT OF MOBILE MARKETING IT PROJECTS: OPPORTUNITIES FOR MOLDOVA AND UKRAINE
}

\author{
Maryna CHAIKOVSKA ${ }^{1}$, PhD in Economics, Associate Professor, \\ Department of Marketing and Business Administration, \\ Faculty of Economics and Law, Odessa Mechnikov National University, Ukraine \\ Alla LEVITSKAIA ${ }^{2}$, Habilitation in Economics, Professor, \\ Faculty of Economics, Comrat State University, \\ Regional Economic Development Institute, Republic of Moldova
}

DOI: https://doi.org/10.36004/nier.es.2020.2-05

JEL Classification: L86, M0, M3, M31, L86

UDC: $339.138: 004.738 .5(477+478)$

\section{ABSTRACT}

This article describes the main problematic issues and modern approaches to managing and developing mobile marketing IT projects. In this study, the authors set the goal of the study - to analyze the features of IT project management in mobile marketing, to systematize the development models of modern web projects and to study the possibilities of using flexible applied methodologies that formalize the development and modification of web applications based on the use of effective methods for managing IT projects in mobile marketing. To achieve this research goal, the authors used theoretical and conceptual analysis, studied existent empirical databases for the mobile application market in the Republic of Moldova and Ukraine. The authors highlighted the critical problems of using agile methodologies in IT projects of mobile marketing. A comparative analysis of the feature's applicability of IT project management methodologies and problems of their using in mobile marketing applications are presented. The logical and structural diagram of the stages of the Mobile App Design Timeline is proposed, which contributes to increasing the effectiveness of the implementation of information technology projects in general. To assess the applicability of the flexible methodologies of Kanban and Scrum, an IT project of mobile marketing was simulated. The significance of the results obtained is predetermined by the fact that they could form a theoretical base for improving the effectiveness of marketing activity under conditions of the informatization of society through the building a selforganizing team and use of agile methodologies in mobile marketing IT projects.

Keywords: mobile marketing, mobile marketing IT project, flexible IT project management methodologies, MVP - minimum viable product.

Articolul descrie principalele provocări și abordări moderne pentru gestionarea și dezvoltarea de marketing mobil a proiectelor IT. În acest studiu, autorii au stabilit obiectivul studiului - să analizeze caracteristicile managementului proiectelor IT în marketingul mobil, să sistematizeze modelele de dezvoltare ale proiectelor web moderne și să studieze posibilitățile de utilizare a metodologiilor aplicate flexibile care să formalizeze dezvoltarea și modificarea de aplicații web bazate pe utilizarea unor metode eficiente pentru gestionarea proiectelor IT în marketingul mobil. Pentru a atinge acest obiectiv de cercetare, autorii au folosit analize teoretice și conceptuale, au studiat baze de date empirice existente pentru piața aplicațiilor mobile din Republica Moldova și Ucraina. Autorii au evidențiat problemele critice ale utilizării metodologiilor agile în proiectele IT de marketing mobil. Este prezentată analiza comparativă a metodologiilor de gestionare a proiectelor IT și a constrângerilor de utilizare a acestora în aplicațiile de marketing mobil. Se propune diagrama logică și structurală a etapelor Programului de proiectare a aplicațiilor mobile, care contribuie la creșterea eficacității implementării proiectelor de

${ }^{1}$ ID ORCID: 0000-0002-9490-5112 $₫$ e-mail: chmp@ukr.net

2 ID ORCID: 0000-0002-0520-805X $₫ e$-mail: alla.levitskaia@gmail.com

December No. 2/2020 
tehnologii informaționale în general. Pentru a evalua aplicabilitatea metodologiilor flexibile ale Kanban și Scrum, a fost modelat un proiect de marketing mobil IT. Semnificația rezultatelor obținute este predeterminată de faptul că acestea ar putea forma o bază teoretică pentru îmbunătăţirea eficacității activității de marketing în condițiile informatizării societății prin construirea unei echipe de autoorganizare și utilizarea metodologiilor agile în proiecte IT de marketing mobil.

Cuvinte-cheie: marketing mobil, marketing IT proiect IT, metodologii flexibile de gestionare a proiectelor IT, MVP - produs viabil minim.

В данной статье описаны основные проблемные вопросы и современные подходы $к$ управлению и развитию мобильного маркетинга ИТ-проектов. Цель исследования проанализировать особенности управления ИТ-проектами мобильного маркетинга, систематизировать модели развития современных веб-проектов и изучить возможности использования гибких прикладных методологий, формализующих процессы разработки и модификации веб-приложений на основе применения эффективных методов управления ИТпроектами мобильного маркетинга. Для достижения цели исследования авторы использовали теоретический и конщептуальный анализ, изучили существующие эмпирические базы данных рынка мобильных приложений в Республике Молдова и Украины. Авторами были выделены критические проблемы использования гибких методологий в ИТ-проектах мобильного маркетинга. Проведенный сравнительный анализ применимости данной методологии управления ИТ-проектами и проблем их использования в приложениях для мобильного маркетинга, позволил авторам предложить логическую структурную схему этапов разработки мобильных приложений, применение которой способствует повышению эффективности реализации проектов в сфере информационных технологий в целом. Для оценки применимости гибких методологий Kanban и Sсruт авторами был смоделирован ИТ-проект мобильного маркетинга. Значимость полученных результатов определяется тем, что они могут стать теоретической базой для повышения эффективности маркетинговой деятельности в условиях информатизации общества за счет построения самоорганизующейся команды и использования гибких методологий в ИТ-проектах мобильного маркетинга.

Ключевые слова: мобильный маркетинг, мобильный маркетинг, ИТ-проект, гибкие методологии управления ИТ-проектами, МVP - минимально жизнеспособный продукт.

\section{INTRODUCTION}

Statement of the problem in general form and its connection with important scientific or practical tasks. The use of certain marketing concepts in enterprises is mainly due to the characteristics and trends of the market. In the process of market transformation, the marketing approach to it is changing.

One of the global modern trends in digital marketing is the steady growth of mobile traffic, which is associated with both an increase in the number of mobile users, mobile Internet connections, mobile communications, and an increase in the speed of data transmission on mobile networks. The average annual growth rate of mobile traffic over the next five years will amount to $60-70 \%$. Mobile devices will generate more than 90 percent of traffic in 2020. In 2019, over two-thirds of Ukrainians and Moldovans are connected to the Internet, most of them using mobile devices to access the Internet (Douglas, 2019).

Today, mobile marketing is the preferred method of digital marketing - a set of promotions, events and campaigns carried out through mobile devices via SMS (Short Message Service) to promote goods and services (Danilenko, 2014:174).

With the transition to the mobile marketing model, the processes of adapting and modifying the new functionality of web applications are accelerated, which requires the use of effective and adequate technologies for managing mobile marketing IT projects (creation of web applications for use with mobile devices). Reducing the timing of such projects, increasing the requirements of usability and the need for dynamic improvement of the quality assurance functionality requires formalizing the processes of web application development and modification based on the application of effective methods of managing mobile marketing IT projects. 


\section{SCIENTIFIC APPROACH AND LITERATURE REVIEW}

According to the classic definition of the American Marketing Association: "Marketing - a function of the organization, which includes a set of processes for creating, promoting and the supply of consumer values through the management of customer relations, as a result of which the organization bears risks and benefits". Research on digital transformation of marketing; places of digital marketing in modern conditions of social development; features of digital marketing as a modern tool of communication management with consumers; components and tools of digital marketing are dedicated to the work of many domestic and foreign scientists: Oklander M. (2017), Oklander T., Yashkina O., Pedko I. (2018), Danilenko M. (2014), Gritsenko S. (2017), Ruban V. (2017), Shafalyuk O. (2017), Kwilinski A., Trushkina N. (2017), Kotler F. (2018), Kaplan A. (2012), Jeffrey M. (2018), Lengard I. (2017).

The analysis of the essence, prospects, methods, features and tendencies of the development of mobile marketing in the world and in Ukraine was carried out in the works of Mazurenko V.P., Matviienko N. (2011), Marchuk O. (2018), Romanenko O. (2015), Yatsyuk D. (2015). The issue of ITproject management at the theoretical level is considered in the works of Bourque P., Fairley R.E (2014), Fatrell R., Donald Schafer F., Larman K., Cohn M., Cobb G. (2016), developed plenty of standard methodologies for process manufacturing software: ISO9001, IS012207, IS015504, CMM (Capability Maturity Model), MSF (Microsoft Solution Framework), RUP (Rational Unified Process), SCRUM, XP (eXtremal Programming), Crystal Clear, ASD (Adaptive Software Development), Agile (2018:68).

Author Bhalla (2011) proved that the marketing strategy should focus on strengthening the interaction between seller and consumer. However, the researchers did not identify areas for monetization of the proposed solutions.

Authors Iliashenco, Ivanova (2015) emphasized the importance of operational transactional interaction in real time. They have systematized the main methods and tools of digital marketing, the specifics of their application. But digital marketing tools are rapidly being upgraded and the results of such research need to be developed. The research study of Oklander, Oklander, Yashkina (2018) contains an analysis of current trends in marketing research in the Internet environment.

However, it seems that the study is not complete because no strategic solutions are proposed. In particular, in the field of mobile marketing, which is progressing most rapidly among other areas of digital marketing. Authors Oklander, Oklander, Yashkina (2017) systematized the classic tools of digital marketing and general aspects of the application of digital technologies. This does not show the trends that have given rise to innovative digital technologies.

Analysis of the literature on the comparison of technological innovations of digital marketing in terms of improving their effectiveness shows that, firstly, the research is fragmentary and does not show the system of their latest most effective tools, does not show their strengths and weaknesses. Secondly, although the issue of mobile marketing is being reprinted in research, not enough attention is paid to the strategies of its monetization. Third, in the presence of multivariate models of affiliate marketing development, their systematization and characteristics of each model are not proposed.

Thus, to develop effective marketing strategies in the digital economy there is a need to improve the theoretical foundations for the use of innovative digital marketing tools, develop recommendations for effective strategies for their monetization and the formation of affiliate marketing models.

Highlighting the previously unresolved parts of the general problem to which the article is devoted. However, all attempts of formalization have failed, uniqueness of mobile marketing IT projects highlights the issue of choice of methods, practices and rules of lowering project risks.

Formulation of the purpose of the article (statement of the problem). The purpose of this study is to analyze the features of a mobile marketing IT project management, systematize the development models of modern web projects, highlight critical problems of using flexible methodologies in mobile marketing IT projects, and develop recommendations for overcoming them.

DATA SOURCES AND METHODS USED

Mobile applications are one of the most successful and promising marketing channels to date. According to Gartner, more than 10 billion mobile devices are registered in the world in 2019, including 1.7 billion machine-to-machine (M2M) connections. The number of mobile users has grown 
from 4.3 billion in 2012 to 5.3 billion in 2019 . The current annual growth rate is $2.4 \%$. The average mobile data rate has increased more than 7-fold since 2012 (Gartner Special Report, 2020).

The highest Internet speed in the world is in South Kore with $95.1 \mathrm{mbps}$, and within a year this figure grew by $120 \%$. In 2019, this country was the first in the world to launch $5 \mathrm{G}$ high-speed Internet. In second place by speed we have Qatar (69.1 mbps), third place - Norway (68 mbps). The average speed of mobile Internet across the world is $29.5 \mathrm{mbps}$. Global mobile traffic in 2019 increased by $30.6 \%$ compared to 2017 , and in the desktop segment it dipped by $3.3 \% .70 \%$ of searches come from mobile devices, up to $30 \%$ of visitors go to sites and leave orders from mobile devices, the average user spends at least 87 hours on performing Internet search activities (Digital Marketing by the Numbers, 2020).

The country with the highest prevalence of smartphones was South Korea - 94\% of adults use smartphones and $6 \%$ use phones. On second place there is Israel with a smartphone prevalence of $83 \%$, in third place is Australia with 82\%. The United States is in eighth place with 77\% (Jomer 2020).

Smartphone sales in the EU and app downloads have increased exponentially over the past years and already over half of Internet access is via mobile devices - and it's still growing. Moreover, most mobile Internet usage is through apps rather than web browsers [11]. The increasing adoption of smartphones and tablets is driving the growing demand for mobile applications. European spending on mobile applications (including user spending and advertising), totaled €6.1 billion in 2013 and by 2018 it grew to $€ 18.7$ billion - so a more than 3-fold increase in just 5 years' time (EU Export Explorer on IT Services, 2016).

Android is the leading operating system for mobile devices in Europe. Other mobile operating systems include Apple's iOS (running only on iPads, iPhones and the Apple Watch) and Windows (unlike Google and Apple, Microsoft has only one OS for desktop computers, laptops, tablets and phones). Demand for cross-platform mobile applications is growing (GEN2 Standard, 2016).

The market for mobile applications is changing rapidly. New technological trends are emerging continuously, offering new opportunities for mobile applications. As a result of all these developments big data environments are growing fast and are becoming more complex and dynamic, which results in poor usability and reduced control over applications. There is thus an increasing demand for mobile applications that analyze data that is available to companies, or that makes collection and use of this data possible.

European companies prefer to outsource services to providers within the same country (onshoring). When outsourcing to foreign service providers, nearshore locations are preferred to offshore locations, due to their proximity, language and cultural similarities and little or no time difference. Popular nearshore destinations are, for example, Bulgaria, Poland, Lithuania and Romania. This may be an opportunity for Ukrainian and Moldovan IT Service providers (GEN2 Standard, 2016).

The Government of the Republic of Moldova approved a Strategy for the Development of the Information Technology and Ecosystem Industry for Digital Innovation for 2018-2023. The development of these documents was the base for the growth of IT technologies: the volume of IT services exports in 2011-2016 increased by an average of $10.6 \%$ per annum in Moldova, amounting to $\$ 79.2$ million in 2016, and the share of such services in the total services exports increased from $5.6 \%$ in 2011 to $8.9 \%$ in 2016 (IT Sector Strategic Roadmap for Moldova, 2020).

Western Europe, with a share of $45 \%$ of the total volume, dominates the sales markets in the structure of the Moldovan export of IT services, followed by America (USA, Canada) with a 21\% share and Central and Eastern Europe with a share of 18\%. According to the type of services provided in the ICT sector, 70\% of Moldovan companies' exports are IT services, followed by R \& D services/ engineering services with a 15\% share and BPO (Business Process Outsourcing) services with a 10\% share. In turn, $70 \%$ of the IT services exports relate to application development and testing, while setting up and supporting applications generates about $14 \%$ of these services.

At the same time, it should be noted that large volumes of export of IT services are not reflected in the official external balance sheet, since the work is carried out by freelancers working individually in international companies. Moldova was featured in the Bloomberg Innovation Index and made it into the Top 10 Global Innovation Index (GII) economies in mobile App development (Table 1). Apps represent global commerce in completely digital goods, therefore provide insight into how 
innovation, production, and trade of digitized products and services are evolving in an increasingly globalized digital economy (GII, 2020).

Table 1

Top 10 GII economics in mobile creation

\begin{tabular}{|l|c|c|}
\hline \multicolumn{1}{c|}{ Countries } & $\%$ & Place \\
\hline Cyprus & 100.00 & 1 \\
\hline Finland & 66.11 & 2 \\
\hline Lithuania & 63.35 & 4 \\
\hline Israel & 59.41 & 5 \\
\hline Estonia & 52.44 & 6 \\
\hline Sweden & 50.17 & 7 \\
\hline Denmark & 49.65 & 8 \\
\hline Korea, Republic of & 48.88 & 9 \\
\hline Moldova, Republic of & 45.90 & 10 \\
\hline Hong Kong (China) & 44.50 & \\
\hline
\end{tabular}

Source: [GII 2020].

Out of $70 \%$ of IT services application development and testing services amounted to $69 \%$ of the share, while application customization and support to 14\% (Figure 1). IT services export are focused on web and mobility app development and include focus on languages such as NET, Enterprise Java, C, C++, C\#, PHP, Sitecore CMS, iOS, Oracle DB and Cisco networks.

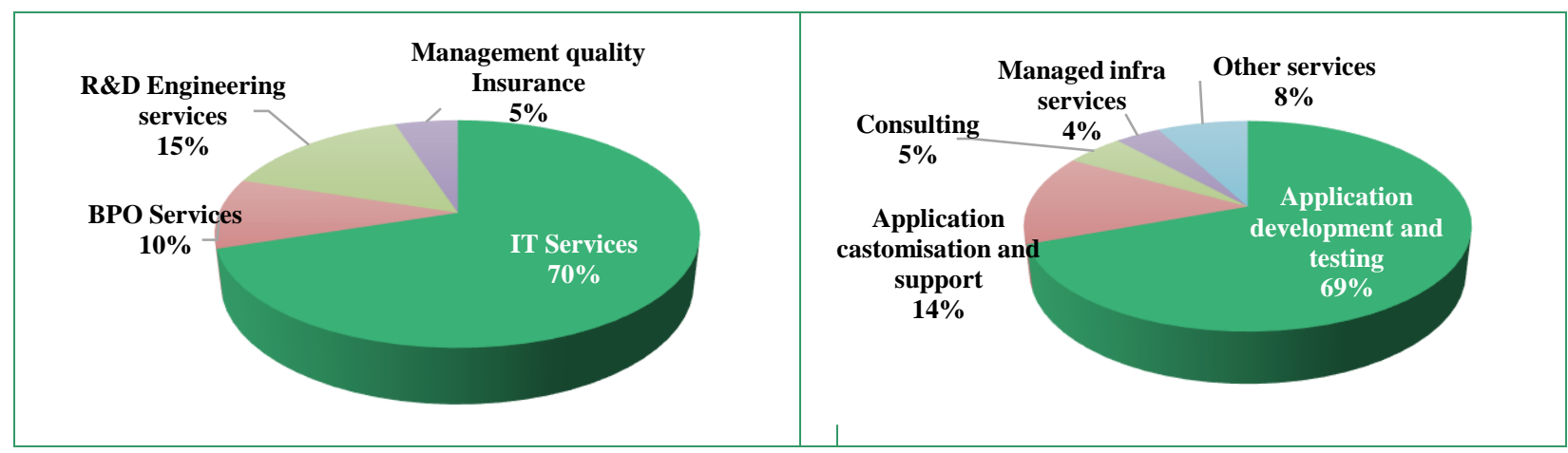

Figure 1. IT services export

Source: [IT Sector Strategic Roadmap for Moldova 2020].

Moldova has a relatively high level of Internet penetration. In 2012, Moldova was significantly behind in this indicator and held only the 37th place in Europe. But in recent years, the country has shown accelerated growth. In 2016, the number of people over 6 years of age using the Internet was $71 \%$, compared with $63 \%$ in 2015 . In 2017 , the number of mobile telephony service users who used 4G mobile Internet via smartphones increased by $45.8 \%$. The volume of traffic generated by mobile Internet users via smartphones in 2018 increased by $64.2 \%$. As a result of such dynamics, the penetration rate of mobile Internet access services per 100 residents in 2019 increased by 14.3 percentage points and amounted to $82.7 \%$.

Similar global trends are observed in Ukraine. The use of the second and third screens is growing, people are using several mobile devices at the same time. In 2019, the number of Ukrainians in the network amounted to almost 23 million, or $71 \%$ of the population, against $63 \%$ of the population in 2018. 66\% of Ukrainian Internet users use mobile devices. $76.2 \%$ of mobile Internet users access the network via Android, 22.5\% through Apple devices (Digital report, 2019).

Increasing importance of mobile traffic requires a change in approach to the development of modern web-projects with a focus on improving usability based on the principles of ergonomics and customer-centricity. The issue of web application development, adapted for use with mobile devices, is critical in digital marketing. Mobile versions have a number of features that must be considered to ensure high usability. Ergonomics means fitness for use, availability of conditions and pre-conditions 
for easy, enjoyable, non-burdening use. There are several usability models: responsive web design, adaptive design, Mobile First, Mobile Only (Table 2).

Table 2

Models of development of modern web-projects

\begin{tabular}{|c|c|c|c|}
\hline Type & Characteristics & Advantages & Limitations \\
\hline $\begin{array}{l}\text { Responsive } \\
\text { web design }\end{array}$ & $\begin{array}{l}\text { The site is readable on } \\
\text { various monitors, does not } \\
\text { require zooming or scaling, } \\
\text { there is no need for } \\
\text { horizontal scrolling. }\end{array}$ & $\begin{array}{l}\text { The need to develop only } \\
\text { one version of the design } \\
\text { that will automatically } \\
\text { adapt to the screen size } \\
\text { of the device. }\end{array}$ & $\begin{array}{l}\text { Excessive overload of web page traffic } \\
\text { (by downloading CSS styles and } \\
\text { JavaScript files); } \\
\text { difficulties with image adaptation. }\end{array}$ \\
\hline $\begin{array}{l}\text { Adaptive } \\
\text { design }\end{array}$ & $\begin{array}{l}\text { The content is automatically } \\
\text { adapted to the screen of the } \\
\text { device used by the user. } \\
\text { First, the developer creates } \\
\text { content for PC users, and } \\
\text { only then "trims" for the } \\
\text { smartphone. }\end{array}$ & $\begin{array}{l}\text { Wide versatility. } \\
\text { Suitable for almost any } \\
\text { category of websites. }\end{array}$ & $\begin{array}{l}\text { Difficulty in adapting an existing site; } \\
\text { significant requirements for the choice } \\
\text { of server solutions }\end{array}$ \\
\hline Mobile-first & $\begin{array}{l}\text { Development of web-based } \\
\text { solutions for mobile users, } \\
\text { with further adjustments to } \\
\text { those solely for workplace } \\
\text { users. }\end{array}$ & $\begin{array}{l}\text { Laconic design, } \\
\text { Minimal functionality. } \\
\text { The connection speed of } \\
\text { the network is taken into } \\
\text { account. }\end{array}$ & $\begin{array}{l}\text { Requires more detailed work on the } \\
\text { prototyping and development phase } \\
\text { of the site concept, given the need to } \\
\text { reduce the amount of content. Design } \\
\text { is limited, scripts are truncated, } \\
\text { background images are missing, } \\
\text { images are minimized. }\end{array}$ \\
\hline Mobile Only. & $\begin{array}{l}\text { mobile users only receive } \\
\text { content that is prepared for } \\
\text { their screen and device } \\
\text { solution. }\end{array}$ & $\begin{array}{l}\text { reducing page load time } \\
\text { on mobile devices by } \\
\text { reducing the number of } \\
\text { resource downloads } \\
\text { requests. }\end{array}$ & $\begin{array}{l}\text { There are risks associated with } \\
\text { browser incompatibilities, differences } \\
\text { in operating systems (OS) of user } \\
\text { devices, restrictions on the mobile } \\
\text { version only. }\end{array}$ \\
\hline
\end{tabular}

Source: Developed by the authors.

Improper model selection causes the site to lose a large share of the market. To provide the most user-friendly interface and navigation, an adequate choice of technology is required at the stage of designing the structure of the web-resource and program code. When choosing a technology, consider the limitations of content minimalism requirements, the complexity of the project, the type of device screens, mono- or multi-variant versions of web-projects, the type of operating system that will be applied.

Mobile marketing IT project management methodologies can be divided into traditional and flexible (iterative). Traditional - based on fairly strict planning of the project before launch and minimal interventions after. With this approach, each subsequent phase begins after the completion of the previous one. The traditional approach correlates with the classic project management standard from PMI - PMBOK (PMBOK, 2018).

Agile Agencies are more effective in a rapidly changing business environment. Agile methodologies encourage change at all stages. This makes them more competitive in current realities. The use of flexible methodologies in the management of IT projects for mobile marketing increases the manageability of the project and allows you to get an effective return on investment; provide structure flexibility.

Agile methodologies are based on adaptive development, focusing on people and their interaction, rather than on processes and tools. They are characterized by flexibility, iterativeness, adaptability. Conducive to breaking into small manageable work packages.

An iterative and incremental approach to project and product management, focused on the dynamic formation of requirements and ensuring their implementation as a result of constant interaction within self-organizing working groups consisting of specialists of various profiles. A working product is more important than comprehensive documentation; cooperation with the 
customer is more important than agreement on the terms of the contract; readiness for change is more important than following the original plan. Suitable for open end projects.

The share of Agile projects in the total array is steadily increasing (from $9 \%$ in 2010 to $25 \%$ in 2019), while traditional approaches are losing popularity, which is particularly noticeable in application development (COBB, 2016:115). Among the methods based on the ideas of Agile, the most popular are Scrum and Kanban.

Kanban (Toyota, 1953) a development management method that implements the principle on time and contributes to an even distribution of workload between employees. The product increment is passed forward from stage to stage, and at the end, an element ready for delivery is obtained. Accurate calculation of the load on the team, the correct placement of constraints and focus on continuous improvement. The main task of Kanban is to reduce the amount of "work currently in progress". In Kanban, estimates of the deadlines for the task are optional or none at all. Kanban is a tool for visualizing the process and limiting the execution of the simultaneous number of tasks, but it alone is not enough for a successful project. Suitable for fairly cohesive teams with good communication.

Scrum is the most structured of the Agile family, combines the elements of the classical process and the ideas of a flexible approach to project management. Scrum is a set of principles on which the development process is built, which allows to provide a product to a customer in hard-fixed and shortterm iterations, called sprints. The scrum methodology is aimed at interacting with the customer, and despite the fact that the development team decides what tasks it will perform during one iteration, there is a leader (scrum master) in this methodology who monitors the process. Using this methodology makes it possible to identify and eliminate deviations from the desired result at earlier stages of software product development.

Table 3 shows a comparative analysis of the features and areas of applicability of flexible methodologies for managing mobile marketing IT projects.

Table 3

Analysis of the application of IT project management methods in the company

\begin{tabular}{|c|c|c|}
\hline Method & Features & Usage in projects \\
\hline $\begin{array}{l}\text { Micro- } \\
\text { management }\end{array}$ & $\begin{array}{l}\text { Problems regarding involving the team in the } \\
\text { development process; } \\
\text { internal security threat (project, information, } \\
\text { staff). }\end{array}$ & $\begin{array}{l}\text { The number of people in the project } \\
\text { does not exceed 10. Leadership lacks } \\
\text { delegation skills or is reluctant to } \\
\text { delegate. }\end{array}$ \\
\hline Kanban boards & $\begin{array}{l}\text { Just in time (JIT) principle. } \\
\text { Helps to identify bottlenecks in the project. } \\
\text { A visual solution that involves prioritizing. } \\
\text { Panoramic view of the project. } \\
\text { Provides business opportunity to be reactive to } \\
\text { customer needs. It's hard to combine testing and } \\
\text { development in one team. }\end{array}$ & $\begin{array}{l}\text { Task-oriented. } \\
\text { High volume of tasks. } \\
\text { The requirements are constantly } \\
\text { changing. } \\
\text { Many tasks may be out of date and get } \\
\text { "demoted". }\end{array}$ \\
\hline Scrum & $\begin{array}{l}\text { Aims for interaction with the customer. More } \\
\text { communications. The beginning of the sprint is } \\
\text { accompanied by planning: analysis and evaluation } \\
\text { of tasks. Weekly mandatory stand-ups. After the } \\
\text { sprint, a retrospective is held. } \\
\text { As a result, all communications (meetings, } \\
\text { workshop, sprint retrospective, etc.) take about } \\
30 \% \text { of the time. }\end{array}$ & $\begin{array}{l}\text { Team-oriented. } \\
\text { Projects with flexible workflow } \\
\text { algorithm, uncertainties, variable } \\
\text { requirements, inability to determine } \\
\text { the time limits of tasks in advance. } \\
\text { Quick launch of the project with the } \\
\text { most priority functions. }\end{array}$ \\
\hline
\end{tabular}

Source: Developed by the authors.

When using flexible methodologies in mobile marketing IT projects, it is necessary to take into account a number of critical problems associated with determining the target market, designing, prototyping, organizing teamwork, and choosing the MVP functionality (minimum viable product). Underestimating the importance of these issues leads to the fact that only 29 out of 100 IT mobile marketing projects reach the stage of successful implementation (Chaikovska, Chaykovskyy, 2018:68). 
Figure 1 shows the logical and structural diagram of the Mobile App Design Timeline stages, which helps to increase the effectiveness of the project.

1. Building an autonomous, self-organizing team in practice. Such a team may not be considered completely independent; leadership is still being implemented: goals are set from the outside, and the team itself is formed by management. However, the team independently determines the path by which the goal will be achieved.

2. Decide what functionality will be the MVP (minimum viable product), how to think of architecture for future expansion, what technologies to choose, and, in addition, determine the time and cost of the project. In order to optimize this process, it is recommended to carry out the design. Designing requires applications with unique, deliberately new functionalities that integrate many features and systems that provide ambiguity for possible solutions.

3. Ignoring the principles of building interfaces for Android and requirements for iOS, laying the wrong structure of screens. Application of non-native elements. This makes the app unintelligible to the user and increases the development time. The lack of clarity of the scripts in the TK and their detailing in the design, the difficulty of integrating the mobile application with CRM systems and ERP.

4. Conducting A/B-testing of the apps and the retrospective of the IT project. In practice, it often turns out that carrying out a retrospective at the end is difficult: the team does not have enough time, many problems are already solved during the iteration.

Effectiveness of Scrum and Kanban

\begin{tabular}{|l|c|c|c|c|c|}
\hline \multirow{2}{*}{ Model } & \multicolumn{2}{|c|}{ Duration (days) } & \multirow{2}{*}{ Deviation (\%) } & \multicolumn{2}{c|}{ Cost (\$) } \\
\cline { 2 - 3 } \cline { 5 - 6 } & Base & Factual & Estimate & Factual \\
\hline Kanban & 40 & 46 & $15 \%$ & $13400 \$$ & $15410 \$$ \\
\hline Scrum & 40 & 35 & $-12,5 \%$ & $13400 \$$ & $11725 \$$ \\
\hline
\end{tabular}

Source: Developed by the authors using COBB G (2016).

To evaluate the applicability of Kanban and Scrum, a mobile marketing IT project was modeled. Despite the fact that the baseline duration of a project modeled using the Scrum methodology is the same as the duration of a project implemented using Kanban, the variance in both the duration and cost of a project modeled using the Scrum methodology is much less than in Kanban with an obvious gain in product quality.

Table 5

\begin{tabular}{|l|c|c|}
\hline \multicolumn{1}{|c|}{ Criteria } & Scrum & Kanban \\
\hline Evaluation of terms & + & - \\
\hline Long-term planning & + & - \\
\hline Roles & + & + \\
\hline Changes after scheduling & - & - \\
\hline Technical task & + & + \\
\hline Quick reaction & - & - \\
\hline Narrow specialization in the team & + & + \\
\hline Daily meetings & + & - \\
\hline The division of tasks into several stages & + & \\
\hline
\end{tabular}

Source: Developed by the authors using COBB G (2016).

The basis of flexible IT project management methodologies is a retrospective. However, there are various approaches to conducting a retrospective, to choosing a model and an algorithm for its implementation. According to the cascade model, a retrospective should be carried out in the late stages of an IT project. An alternative approach recommended in benchmarking is the continuous retrospective of an IT project. The main feature of this approach is the departure from a phased model to a spiral one, with daily milestones ("stand-up" assemblies) (Chaikovska, 57).

Continuous retrospective is implemented by the following activities: visualization of the problem, development of a business process model for its implementation, analysis of alternative options for its operational resolution.

December No. 2/2020 


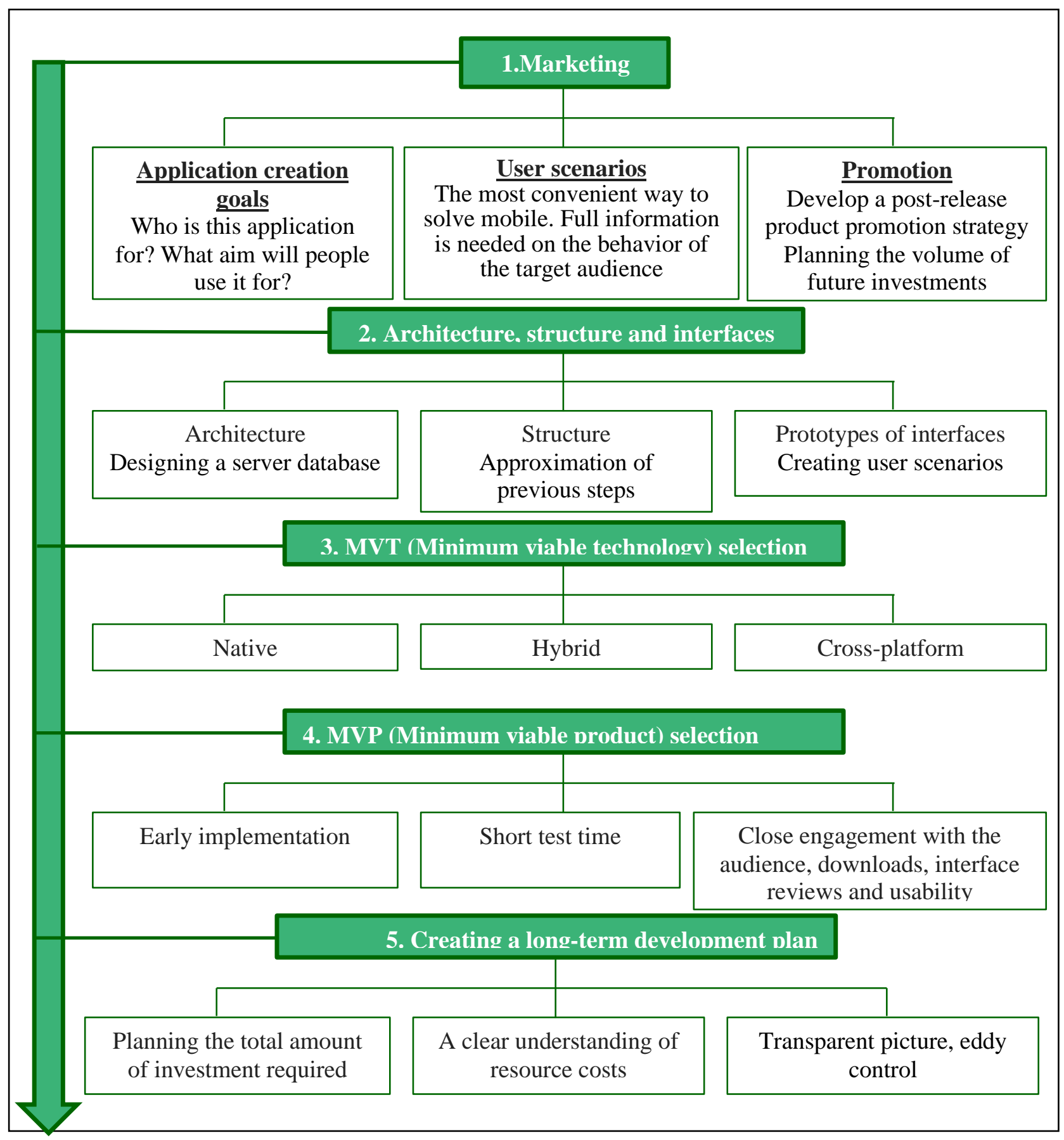

Source: [Chaikovska, 2017].

Figure 2. Mobile App Design Timeline

\section{CONCLUSIONS AND PROSPECTS FOR FURTHER DEVELOPMENTS}

Mobile marketing is constantly evolving. In a world where people read their correspondence, socialize and search for different information through mobile devices, businesses need new marketing strategies and tools, new approaches to managing. Applying these flexible approaches will encourage customers using mobile services to visit the site. It will contribute to creating applications that provide unique usability content, and among other things, digital presence.

One of the main tasks that directly affect the effectiveness of software development is choosing a model for the development process. There is no single optimum choice. The model may vary depending on the scale, novelty and criticality of the project, distribution of participants, customer requirements. Today, the traditional approach to managing IT projects is having considerable difficulties when project 
requirements can change at almost any stage, as it is necessary to respond to the rapidly changing environment.

These are exactly the challenges inherent to mobile marketing IT projects. Flexible methodologies have their own challenges. It is important to perceive them as "challenges" and not advantages or disadvantages. Micromanagement and Kanban are good for small business website projects that don't take much time to plan. Scrum is suitable for a large project (3 months in duration) that has full specification and requirements before development begins.

In this case, the team can easily draw up a detailed development plan and split the whole process into a sprint. Implementing Scrum and switching to flexible methodologies takes time and effort. A flexible team goes through the stages of formation, conflict, normalization, and cooperation. Productive work is only possible at the last stage, at which point the manager needs to help and support the team.

The transition to flexible methodologies involves a dramatic change in the tasks and methods of executives' work. The leadership style of the manager should focus on delegation, virtually all authority is transferred to the team, and the task of the manager is to teach them to act independently, organize and support the work process.

The underlying complexity of using flexible methodologies is that it is not just a change in the work process, it is also a change of mindset: working together to achieve a goal that determines the direction of further research. These recommendations will have a practical approach for IT companies of the Republic of Moldova and Ukraine.

\section{REFERENCES}

1. OKLANDER, M. et al. Analysis of technological innovations in digital marketing. In: Eastern-European Journal of Enterprise Technologies. 2018, vol. 5, no 3, pp. 80-91. ISSN 1729-3774, ISSN 1729-4061. DOI: 10.15587/1729-4061.2018.143956 [cited 03 june 2020]. Available: file://C:/Users/ANGELA 1.CAT/AppData/Local/Temp/143956-312504-1-PB.pdf

2. BOURQUE, P., FAIRLEY, R.E., eds. Swebok V 3.0. Guide to the Software Engineering Body of Knowledge. 2014. 335 p. ISBN 978-0-7695-5166-1 [cited 19 august 2020]. Available: https://cs.fit.edu/ kgallagher/Schtick/Serious/SWEBOKv3.pdf

3. CHAIKOVSKA, M. Methodological bases of IT-Project management with simulation modeling tools. In: Scientific Journal of Polonia University. PNAP. Periodyk naukowy Akademii Polonijnej, Częstochowa, Akademia Polonijna w Częstochowie. 2017, vol. 21, no. 2, pp. 55-66. ISSN 1729-3774. DOI: http://dx.doi.org/10.23856/2106

4. CHAIKOVSKA, M., CHAYKOVSKYY, O. Architectural component-oriented approach to managing it projects. In: OSTOPOLETS, I, MIKOS, P. Technologie innowacyjne w tworzeniu i rozwójukapitału ludzkiego. Innovative technologies in the formation and development of human capital. Katowice: Editorial compilation Wydawnictwo Wyższej Szkoły Technicznej, 2018, pp. 67-80. ISBN 978-83947093-6-5 [cited 15 august 2020]. Available: http://www.wydawnictwo.wst.pl/uploads/files/6510cf744fb8c9ca548253f02492632c.pdf

5. COBB, G. Making Sense of Agile Project Management: Balancing Control and Agility. New York: Wiley, 2016. 265 p.

6. DANILENKO, M. I. Mobile marketing: realities and prospects. In: Scientific Bulletin of the Kherson State University. 2014, № 7 (2), pp. 172-175. ISSN 2413-3337.

7. OKLANDER, M.A., ed. Digital marketing - the 21st century marketing model: monograph. Odessa: Astroprint, 2017. $292 \mathrm{p}$.

8. Digital Marketing by the Numbers: Stats, Demographics \& Fun Facts. 2020, 30 june [cited 22 july 2020]. Available: https://www.omnicoreagency.com/digital-marketing-statistics/

9. JOMER, G. Digital Marketing Trends in 2020 [Infographic]. 2020, 11 february [cited 09 august 2020]. Available: https://www.business2community.com/infographics/digital-marketing-trends-in-2020infographic-02283628

10. JEFFREY, M. Data Based Marketing. 15 key indicators that everyone should know. Per. from English P. MIRONOVA. M.: Mann, Ivanov, 2018. 384 p.

11. MULLIGAN, M, CARD, D. Sizing the EU App Economy. 2014, february. 16 p. [cited 10 july 2020]. Available: http://eurapp.eu/sites/default/files/Sizing\%20the\%20EU\%20App\%20Economy.pdf 
12. EU Export Explorer on IT Services. 2016, november [cited 11 august 2020]. Available: http://invest.gov.md/sites/default/files/EU_EXPORT_EXPLORER_EN.pdf

13. Gartner Special Reports: Providing actionable insights into major trends [cited 22 march 2020]. Available: http://www.gartner.com/technology/research/digital-business

14. GEN2 Advisors. Blurring of Offline and Online Worlds. 2016.

15. GRITSENKO, S.I. Digital marketing is a new paradigm for the development of educational clusters in the context of globalization. In: Bulletin of economic science of Ukraine. 2017, no 1 (30), pp. 29-31.

16. IT Sector Strategic Roadmap for Moldova [cited 19 august 2020]. Available: https://mei.gov.md/sites/default/files/2._avasant_it_strategic_roadmap.pdf

17. KAPLAN, A. If you love something, let it go mobile: Mobile marketing and mobile social media $4 \times 4$ Found. In: Business Horizons. 2012, vol. 55, no 2, pp. 129-139. ISSN 0007-6813.

18. KOTLER, F. Marketing 4.0. View traditional to digital. Per. from English. Kyiv, 2018. 208 p. ISBN 978966-948-009-5.

19. KWILINSKI, A., TRUSHKINA, N. Development of digital marketing in conditions of transformational change. In: Research and Innovations: collection of scientific articles. Cornell University. Ithaca, New York, USA: Yonona Publishing. 2017.

20. LENGARD, I. Mobile Marketing for Business. New York: Wiley. 2017. 446 p.

21. LEVITSKAIA, A., IANIOGLO, N. Digital marketing technologies as an effective tool for promotion of tourism in the Republic of Moldova. In: Marketing and digital technologies. 2018, vol. 2, no. 3, pp. 7784. ISSN 2522-9087 [cited 13 june 2020]. Available: http://mdtopu.com.ua/index.php/mdt/article/view/46/45

22. MARCHUK, O.O. Digital marketing as an innovative management tool. In: Economy and society. 2018, no. 17, pp. 296-299 [cited 11 august 2020]. Available: http://economyandsociety.in.ua/journal/17_ukr/43.pdf

23. MAZURENKO, V.P., MATVIIENKO, N.O. Development of mobile marketing in Ukraine. In: Marketing and Management of Innovations. 2011, vol. II, no. 4. [cited 18 august 2020]. Available: https://mmi.fem.sumdu.edu.ua/sites/default/files/mmi2011_4_2_24_29.pdf

24. NIELSEN, J, LAUREANGER, H. Web Design: Website Usability: monograph. Odessa, 2018. 368 p. ISBN 978-5-8459-1222-0 [cited 23 june 2020]. Available: http://www.williamspublishing.com/PDF/9785-8459-1222-0/intro.pdf

25. OKLANDER, M., OKLANDER, T., YASHKINA, O. Marketing research trends: online panels and online communities. In: Marketing and Management of Innovations. 2018, no. 1, pp. 118-129.

26. OKLANDER, M., ROMANENKO, O. Specific differences of digital marketing from Internet marketing. In: Economic Bulletin of the National Technical University of Ukraine Kyiv polytechnical institute. 2015, no. 12, pp. 362-371. ISSN 2307-5651.

27. Pmbok guide. Sixth Edition. Project Management Institute. 2019. 792 p.

28. RUBAN, V.V. Digital marketing: the role and features of use. In: Economic Bulletin of Zaporizhzhya State Engineering Academy. 2017, issue 2-2 (08), pp. 20-25. ISSN 2312-9395.

29. SHAFALYUK, O.K. Methodological problems and possibilities of development of Internet marketing. In: Marketing and digital technology. 2017, vol. 1, no 1, pp. 108-127. ISSN 2522-9087.

30. DOUGLAS, Karr. The Digital Marketing Landscape. 2019, 8 january [cited 12 august 2020]. Available: https://martech.zone/digital-marketing-landscape/

31. The digital-report-2019 [cited 28 june 2020]. Available: https://wearesocial.com/global-digital-report-2019

32. YATSYUK, D.V. Digital marketing: the future of marketing communications in branding. In: Investment: practice and experience. 2015, no 7, pp. 70-74 [cited 07 June 2020]. Available: http://www.investplan.com.ua/pdf/7_2015/16.pdf

33. Global Innovation Index (GII) 2020: Who Will Finance Innovation? [cited 15 august 2020]. Available: https://www.globalinnovationindex.org/Home

\section{ARTICLE HISTORY}

Received 11 June 2020

Accepted 02 November 2020 